\title{
Faktor-Faktor Yang Mempengaruhi Implementasi Program Usaha Ekonomi Produktif (UEP) Bagi Lanjut Usia Potensial di Kota Yogyakarta
}

\author{
Roni Hermoko \\ Program Pascasarjana, Magister Ilmu Pemerintahan, Universitas Muhammadiyah Yogyakarta Bantul, Daerah \\ Istimewa Yogyakarta 55183, Email: ronihermoko.mip@gmail.com
}

\begin{abstract}
Abstrak: Semakin tingginya persentase Lansia di Indonesia akan menambah beban pemerintah karena akan menambah angka ketergantungan/dependency ratio. Untuk mengurangi beban pemerintah diperlukan sebuah program pemberdayaan bagi Lansia potensial. Salah satu program yang sudah ada adalah Program UEP bagi Lansia Potensial sebagai bentuk investasi sosial diharapkan mengurangi beban pemerintah dengan terwujudnya Lansia yang sehat, mandiri dan bermartabat. Kajian ini memaparkan faktor - faktor yang mempengaruhi implementasi program UEP bagi Lansia potensial di Kota Yogyakarta. Faktor yang memberikan pengaruh positif dalam implementasi program antara lain kapasitas organisasi yang terdiri dari struktur birokrasi yang simple structure, model komunikasi dan koordinasi secara formal dan informal; kondisi lingkungan yang terdiri dari kondisi sosial, ekonomi, dan budaya masyarakat; serta variabel penerima manfaat yang dilihat dari mudahnya program dilaksanakan dan perubahan positif untuk kehidupan sosial penerima manfaat. Variabel yang memberikan pengaruh negatif antara lain variabel konten kebijakan yaitu belum adanya peraturan tentang Lansia di Provinsi dan Kota, tidak sampainya pesan peraturan nasional kepada implementor; variabel kapasitas organisasi tentang sumberdaya yaitu kurangnya pelatihan kepada Pekerja Sosial Masyarakat (PSM) menyebabkan kurang maksimalnya pendampingan program, variabel kondisi lingkungan terkait dukungan pemerintah Kelurahan yang kurang memberikan perhatian dan Dinas Sosial tidak memiliki Standar Operasional Prosedur (SOP) monitoring dan evaluasi program. Dengan kondisi seperti itu, maka diperlukan adanya advokasi ke Pemerintah Kota untuk segera memiliki peraturan yang bisa menjadi pedoman pelaksanaan program, mendorong Dinas Sosial untuk segera memiliki SOP monitoring dan evaluasi program, mendorong Pemerintah Kelurahan untuk melakukan inisiasi kegiatan kelanjutusiaan, meningkatkan kapasitas sumber daya manusia PSM yang menjadi pendamping program.
\end{abstract}

Kata kunci: Implementasi Program, Lanjut Usia Potensial, Usaha Ekonomi Produktif.

\begin{abstract}
Increasing number of ageing populations in Indonesia consequently will add burden to government as ageing population increases dependency ratio. In order to reduce the burden to government, empowerment program for potential elderly is required. One of empowerment programs that exist is Usaha Ekonomi Produktif (UEP) or Productive Economic Enterprise program. As a social investment program, this UEP program aims to help elderly to live healthy, independently and with dignity. This study will describe factors that influence UEP program for potential elderly in Yogyakarta. Factors that positively influence UEP implementation are: organization capacity (simply-structure bureaucracy, communication model and formal/informal coordination); favorable environment (social, economy and cultural condition of community); beneficiary factor (how program implemented, impact to beneficiaries). While factors that negatively influence UEP are: policy content (no regulation on elderly in Yogyakarta province and city, non-adherence to national regulation by local implementor); organization capacity (lack of training to community social worker or PSM causes unmaximized mentoring program); environment (lack of support from village administration, non-existence of standard operating procedure of program monitoring and evaluation). Learning from those condition, this study recommends further advocacy to local government to develop regulation or guideline for program implementation, encourage district social office to implement SOP for program monitoring and evaluation, encourage village administration to support programs for elderly and improve community social worker capacity.
\end{abstract}

Keywords: Program Implementation, Potential Elderly, Productive Economic Enterprise

Article History:

Received : 2020-05-14

Revised : 2020-6-16

Accepted : 2020-7-20

\section{PENDAHULUAN}

Pembangunan kesejahteraan sosial merupakan bagian dari pembangunan sosial yang merupakan upaya untuk menangani permasalahan - permasalahan sosial yang ada dengan 
tujuan meningkatkan kualitas kesejahteraan sosial perorangan, kelompok, dan masyarakat. Salah satu permasalahan sosial yang ada adalah tentang Lansia. Kondisi global mengenai Lansia, berdasarkan data yang dilaporkan oleh Badan Perserikatan Bangsa - Bangsa (PBB) pada tahun 2011 terkait dengan persentase populasi lansia pada tahun 2000 adalah sebesar 7,74 \%. Angka perkiraan persentasi lansia di tahun 2045 adalah sebesar 28,68\%. Begitu pula dengan kondisi nasional, berdasarkan laporan Badan Pusat Statistik (BPS) terjadi peningkatan persentase Lansia. Pada tahun 2015 persentase populasi lansia adalah 8,49 \% dan angka tersebut akan semakin bertambah dan diperkirakan mencapai 15,77 \% di tahun 2035.

Provinsi dengan persentase Lansia tertinggi di Indonesia adalah Provinsi Daerah Istimewa Yogyakarta, berdasarkan data dari BPS yang bersumber dari Susenas tahun 2015, persentase Lansia di Provinsi DI Yogyakarta adalah 13,46 \%. Angka tersebut jauh diatas persentase Lansia nasional. Sementara jika kita melihat angka persentase Lansia Per Kabupaten/Kota yang ada di Provinsi DI Yogyakarta di tahun 2015 adalah sebagai berikut: Kabupaten Gunungkidul 18,79 \%, kabupaten Kulon Progo 17,08 \%, kabupaten Bantul 12,31 \%, kabupaten Sleman 10,97 \%, dan Kota Yogyakarta 9,89 \%. Kota Yogyakarta memiliki persentase Lansia terendah jika dibandingkan dengan kabupaten lainnya di Provinsi DI Yogyakarta, tetapi karena Kota Yogyakarta merupakan satu - satunya Kota di Provinsi DI Yogyakarta, tentunya permasalahan mengenai kesejahteraan sosial, khususnya masalah Lansia akan lebih kompleks. Permasalahan Lansia erat kaitannya dengan permasalahan sosial ekonomi, dimana di daerah perkotaan, permasalahan terkait sosial ekonomi lebih kompleks. Permasalahan tersebut antara lain tentang urbanisasi.

Tingginya tingkat urbanisasi menimbulkan permasalahan turunan yaitu permasalahan permukiman, lapangan pekerjaan, kemiskinan, kriminalitas, polusi dan tatanan sosial kemasyarakatan. Bagi kelompok Lansia, pengaruh urbanisasi akan berdampak bagi mereka. Dari sisi kesehatan, karena semakin tingginya polusi baik polusi udara, air maupun tanah akan menyebabkan semakin cepatnya penurunan kondisi kesehatan mereka karena udara dan air yang mereka konsumsi tingkat pencemarannya tinggi. Ruang publik bagi lansia akan sangat terbatas karena semakin padatnya populasi sehingga ruang yang ada akan dimanfaatkan untuk keperluan bisnis. Dari segi tatanan sosial juga akan ada pengaruhnya, semakin sibuknya kehidupan perkotaan, perhatian keluarga terhadap lansia cenderung menurun karena mereka sibuk untuk mencari penghasilan untuk memenuhi kebutuhan hidup mereka.

Tingkat urbanisasi di Propinsi DIY yang semakin meningkat setiap tahunnya, berdasarkan data dari BPS dalam buku Proyeksi penduduk Indonesia tahun 2010 - 2035 disebutkan bahwa tingkat urbanisasi di DIY lebih tinggi dibandingkan dengan tingkat urbanisasi nasional, berikut data proyeksi tingkat urbanisasi:

Tabel 1. Proyeksi Tingkat Urbanisasi di Yogyakarta Tahun 2015-2035

\begin{tabular}{llllll}
\hline & $\mathbf{2 0 1 5}$ & $\mathbf{2 0 2 0}$ & $\mathbf{2 0 2 5}$ & $\mathbf{2 0 3 0}$ & $\mathbf{2 0 3 5}$ \\
\hline DIY & 70,5 & 74,6 & 78,0 & 81,3 & 84,1 \\
\hline Indonesia & 53,3 & 56,7 & 60,0 & 63,4 & 66,6 \\
\hline \multicolumn{5}{c}{ Sumber: BPS. Proyeksi Penduduk Indonesia Tahun $2010-2035$}
\end{tabular}

Kota Yogyakarta yang merupakan satu - satunya Pemerintah Kota dan memiliki daerah urban yang paling besar akan mengalami tingkat urbanisasi yang semakin tinggi. Selain hal tersebut, berdasarkan data dari BPS dalam buku Statistik Penduduk Lanjut Usia 2017 dapat dilihat bahwa mengenai persentase lansia bekerja di perkotaan lebih rendah daripada di pedesaan. Di perkotaan, Lansia yang bekerja hanya 40,93\%, sementara di Pedesaan Lansia yang bekerja adalah 55,34 \%. Hal ini disebabkan di pedesaan lebih banyak tersedia lapangan pekerjaan bagi lansia, salah satunya adalah di sektor pertanian. Terbukti berdasarkan data bahwa Lansia Pedesaan yang terserap di sektor pertanian mencapai angka 
$74,25 \%$. Sementara di daerah perkotaan, masalah lapangan pekerjaan bagi Lansia masih lebih besar.

Dengan melihat data yang ada dan tren mengenai jumlah Lansia yang semakin berkembang di masa yang akan datang, tentu saja hal tersebut disatu sisi merupakan tantangan, tetapi disisi lain bisa sebagai sebuah peluang baik itu bagi individu, keluarga, masyarakat maupun pemerintah. Dari sudut pandang pemerintah, jumlah lansia akan menjadi sebuah tantangan atau peluang negatif apabila semakin besar jumlah lansia justru akan lebih menambah beban pembangunan. Sebaliknya, jumlah lansia yang besar akan mejadi peluang apabila lansia masih bisa sebagai asset pembangunan. Lanjut usia yang produktif, sehat, aktif dan tidak tergantung kepada orang lain akan membawa dampak positif bagi laju pembangunan, sebaliknya lansia akan menjadi beban pembangunan apabila lansia tersebut dalam kondisi tidak sehat, miskin, tidak berdaya, tergantung pada orang lain dan secara tidak langsung akan menyebabkan meningkatnya biaya perawatan kesehatan.

Sebagaimana diketahui bahwa proses penuaan menjadi lansia adalah sebuah proses alamiah bagi setiap manusia yang tidak bisa dihindari oleh siapa pun dalam kedudukan apapun. Permasalahan umum bagi seorang lansia adalah pada persoalan fisik, mental psikologis dan sosial ekonomi. Berbagai permasalahan ini juga dihadapi oleh keluarga dan lingkungan sosialnya. Ditinjau dari aspek ekonomi bahwa keberadaan lansia dipandang membawa dampak pada penurunan tingkat produktivitas dalam melakukan berbagai kegiatan untuk memenuhi kebutuhannya, baik kebutuhan ekonomi maupun kebutuhan yang lainnya. Dengan demikian, bertambahnya jumlah lansia, maka bertambah pula jumlah penduduk yang tidak produktif, yang selanjutnya akan berdampak pada meningkatnya beban tanggungan penduduk produktif yang berusia 15 - 64 tahun. Data hasil Susenas tentang Indikator Kesejahteraan Rakyat Yogyakarta tahun 2013 - 2016 mencatat bahwa secara rata-rata Angka Beban Ketergantungan/Dependency Ratio di Yogyakarta mencapai 44 pada tahun 2016. Ini artinya bahwa secara ratarata setiap 100 penduduk produktif menanggung sekitar 44 penduduk tidak produktif. Jelaslah bahwa kondisi ini tidak menguntungkan bagi kondisi kesejahteraan sosial di propinsi DI Yogyakarta, terutama kesejahteraan sosial rumah tangga dimana terdapat penduduk lansia.

Berdasarkan gambaran kondisi lansia ini, maka para stakeholder di Kota Yogyakarta perlu memikirkan kebijakan-kebijakan strategis dan operasional untuk menangani masalah lansia secara serius, cepat dan efesien dengan memfokuskan pada dua aspek utama, yakni bagaimana memberikan pelayanan publik yang berpihak pada kesejahteraan lansia dan menciptakan kebijakan - kebijakan yang mengarah kepada pemberdayaan kelompok lanjut usia. Pemerintah sudah seharusnya membuat sebuah perencanaan kebijakan dan program yang ditujukan untuk kelompok lansia sehingga diharapkan lansia dapat berpartisipasi aktif dalam pembangunan, tidak dianggap menjadi beban dan pada akhirnya berdampak pada peningkatan tingkat kesejahteraan lansia. Pemerintah Pusat sebenarnya sudah memberikan payung hukum untuk menjalankan kebijakan terkait kesejahteraan lansia yaitu Undang - Undang No. 13 Tahun 1998 Tentang Kesejahteraan Lanjut Usia. Berbagai Kebijakan dan Program yang dijalankan oleh Pemerintah tertuang dalam Peraturan Pemerintah No. 43 Tahun 2004 Tentang Pelaksanaan Upaya Peningkatan Kesejahteraan Lanjut Usia. Adapun peraturan terbaru adalah Peraturan Menteri Kementerian Sosial No. 4 Tahun 2017 Tentang Pedoman Pengembangan Kawasan Ramah Lanjut Usia. Kemudian, Kementerian Kesehatan RI juga mengeluarkan Peraturan Menteri Kesehatan No. 25 Tahun 2016 Tentang Rencana Aksi Nasional Kesehatan Lanjut Usia tahun 2016 - 2019.

Seiring dengan adanya otonomi daerah, peran Pemerintah Daerah menjadi sangatlah penting untuk bisa menerjemahkan kebijakan dan program dari Pemerintah Pusat tersebut, terutama Pemerintah Kabupaten atau Kota. Terkait dengan masalah lansia, Pemerintah Kota Yogyakarta, yang menjadi satu - satunya Pemerintah Kota di lingkungan Pemerintah Provinsi 
Daerah Istimewa Yogyakarta mempunyai tantangan yang lebih besar jika dibandingkan dengan daerah lainnya untuk segera memiliki kebijakan dan program bagi lansia. Tetapi sampai saat ini, sangat minim perangkat peraturan yang dimiliki Pemerintah Kota Yogyakarta yang bisa mendukung pelaksanaan peraturan - peraturan tingkat nasional tersebut. Belum ada Peraturan Daerah yang khusus mengatur mengenai Kesejahteraan Lanjut Usia di Kota Yogyakarta. Regulasi yang saat ini ada, yang khusus menyoroti tentang lansia adalah Peraturan Walikota Yogyakarta No. 69 Tahun 2006 Tentang Pembentukan Komisi Kota Lanjut Usia Kota Yogyakarta dan Peraturan Walikota Yogyakarta No. 61 Tahun 2013 Tentang Pelayanan Rumah Sehat Lansia Di Kota Yogyakarta.

Perda No. 23 Tahun 2009 Tentang Penanggulangan Kemiskinan, dalam pasal 28 hanya memperhatikan kelompok Lansia terlantar saja. Salah satu Satuan Kerja Pemerintah Daerah (SKPD) di lingkungan Pemerintah Kota Yogyakarta yang mempunyai peran dalam menjalankan program - program kebijakan terkait lansia adalah Dinas Sosial. Program untuk lansia dibedakan antara program yang diperuntukkan lansia Potensial dan non potensial. Untuk lansia non potensial, salah satu programnya adalah Asistensi Sosial Lanjut Usia (ASLUT) dan bagi lansia potensial salah satu programnya adalah Program Usaha Ekonomi Produktif (UEP), yang bertujuan untuk memberdayakan lansia dalam meningkatkan kesejahteraannya khususnya dalam hal perekonomiannya. Keunikan yang dimaksud adanya perbedaan atau kekhasan penelitian yang sedang dilakukan dengan penelitian lain yang sudah dilakukan sebelumnya.

\section{METODE PENELITIAN}

Penelitian ini memfokuskan kepada faktor-faktor yang mempengaruhi implementasi program UEP bagi Lansia Potensial di Kota Yogyakarta. Tujuan penelitian ingin mengetahui faktor-faktor apa saja yang mempengaruhinya. Metode penelitian menggunakan metode kualitatif dan studi dokumen. Metode kualitatif dengan melakukan wawancara kepada Dinas Sosial Kota Yogyakarta, Pekerja Sosial Masyarakat (PSM) dan Lansia penerima manfaat program. Studi dokumen dengan melihat peraturan yang berlaku serta dokumen rencana kerja pemerintah Kota Yogyakarta.

\section{HASIL DAN PEMBAHASAN}

Faktor-faktor yang mempengaruhi implementasi program UEP bagi lansia potensial di Kota Yogyakarta dibagi menjadi dua yaitu faktor internal dan faktor eksternal. Faktor internal terdiri dari isi kebijakan dan kapasitas organisasi. Faktor eksternal terdiri dari kondisi lingkungan setempat dan penerima manfaat.

\section{Faktor Internal Isi Kebijakan}

Untuk pembahasan konten kebijakan, yang menurut penulis merupakan salah satu faktor internal yang mempengaruhi implementasi program, penulis membatasi pembahasan pada dua hal yaitu bagaimana kelengkapan dari regulasi yang menjadi dasar pelaksanaan program Usaha Ekonomi Produktif bagi Lansia Potensial dan mengenai kejelasan pesan dari regulasi itu sendiri sehingga implementor terutama tenaga pendamping lapangan program UEP bagi Lansia Potensial ini mudah memahami dan mengaplikasikannya di lapangan. Menurut teori yang ada, bahwa idealnya semakin jelas dan rinci isi sebuah kebijakan, akan semakin mudah pula diimplementasikan karena implementor mudah memahami dan menerjemahkan dalam tindakan nyata. Sebaliknya, ketidakjelasan isi kebijakan merupakan potensi lahirnya distorsi dalam implementasi kebijakan (Winarno, 2007).

Dilihat dari data hasil wawancara dan studi dokumen, maka konten kebijakan dan kejelasan pesan dapat dilihat suatu keadaan yang selaras dengan teori yang ada. Jika dilihat 
dari konten kebijakan yang ada untuk program UEP bagi Lansia Potensial ini sudah cukuplah lengkap mulai dari Undang - Undang, Peraturan Pemerintah, Peraturan Menteri bahkan Modul yang sebenarnya bisa menjadi panduan bagi PSM dilapangan. Tetapi hal itu hanya ada di tingkat nasional, sementara di tingkat provinsi dan kota belum ada peraturan ataupun payung hukum yang bisa dijadikan pedoman untuk pelaksanaan program ini. Hal kedua, ternyata kejelasan pesan dari regulasi yang mengatur tentang Program Usaha Ekonomi Produktif bagi Lansia Potensial belum sampai atau belum dipahami secara utuh oleh para implementor di lapangan. Hal tersebut bisa dilihat dari temuan bahwa Implementor di tingkat Dinas belum mengetahui hierarki produk perundangan tingkat nasional yang mengatur tentang UEP bagi Lansia potensial, yang diketahuinya hanyalah produk UU No.13 Tahun 1998 tentang Kesejahteraan Lanjut Usia. Pada tingkat implementor di lapangan yaitu PSM yang bertugas mendampingi penerima manfaat juga tidak paham seutuhnya petunjuk tekhnis pelaksanaan program tersebut yang sebenarnya sudah ada modul yang bisa digunakan sebagai pegangan mereka.

Dengan temuan tersebut, maka bisa dikatakan bahwa variabel konten kebijakan yang dilihat dari kelengkapan dan kejelasan pesan regulasi untuk program ini mempunyai pengaruh negatif terhadap implementasi program UEP bagi Lansia potensial di Kota Yogyakarta. Dikatakan demikian karena walaupun regulasi di tingkat nasional sudah lengkap, tetapi tingkat daerah tidak memiliki regulasi yang bisa dijadikan landasan bagi program ini. Selain itu, kejelasan pesan regulasi yang sudah lengkap di tingkat nasional tidak bisa sampai kepada implementor di tingkat dinas maupun implementor di lapangan.

\section{Kapasitas Organisasi}

Kapasitas organisasi akan mempengaruhi bagaimana implementasi Program Usaha Ekonomi Produktif bagi Lansia Potensial, hal - hal yang bisa dilihat dalam kapasitas organisasi yang bisa mempengaruhi implementasi antara lain adalah:

\section{Struktur birokrasi}

Semakin "gemuk" sebuah struktur organisasi akan mengakibatkan semakin rumitnya alur birokrasi yang harus dijalani, yang tentu saja akan menyebabkan ketidak efektifan jalannya implementasi program. Untuk program UEP bagi Lansia Potensial di Kota Yogyakarta ini sebenarnya jika dilihat dari struktur organisasi tidaklah begitu rumit. Jika dilihat dari dokumen Renja SKPD tahun 2017 dan Peraturan Walikota Kota Yogyakarta No. 85 Tahun 2016 tentang Susunan Organisasi, Kedudukan, Tugas, Fungsi dan Tata Kerja Dinas Sosial Kota Yogyakarta maka program UEP bagi Lansia potensial ini berada di Bidang Perlindungan dan Jaminan Sosial, dan lebih tepatnya menjadi program dari Seksi Perlindungan Sosial. Dalam dokumen Renja SKPD tahun 2017 Program UEP bagi Lansia Potensial ini merupakan penerjemahan dari program no.4 di Seksi perlindungan sosial yaitu program Pembinaan bagi Lansia Potensial, yang di implementasikan menjadi Program UEP bagi Lansia Potensial. Tidak ada struktur hierarki yang baku antara implementor tingkat dinas yaitu Kepala Seksi Perlindungan Sosial dengan implementor tingkat lapangan yaitu PSM di masing - masing kelurahan. Yang ada adalah hubungan komunikasi dan koordinasi antara mereka.

Secara teoritis, implementasi kebijakan yang menggunakan simple structure tentu akan memiliki peluang keberhasilan yang lebih tinggi jika dibandingkan dengan implementasi yang menggunakan complex stucture. Sebab biasanya implementasi yang dilakukan oleh organisasi tunggal, hanya ada satu organisasi yang terlibat dalam implementasi. Kondisi ini berbeda ketika implementasi dilakukan dengan melibatkan banyak organisasi yang akan berimplikasi pada komunikasi, koordinasi dan pengawasan yang akan lebih sulit dilakukan (Purwanto dan Sulistyastuti, 2012). 
Jika diamati dari data diatas dan dihubungkan dengan teori yang ada, sebenarnya struktur birokrasi yang ada di dalam implementasi program ini termasuk yang simple stucture, karena hanya Dinas Sosial yang terlibat dan dilapangan langsung berhubungan dengan kelompok kelompok Lansia penerima manfaat dan pendamping lapangan yaitu Pekerja Sosial Masyarakat (PSM). PSM inilah yang terlibat mulai dari penjaringan anggota dalam Kelompok Lansia yang akan mendapatkan bantuan, penyusunan proposal, pendistribusian dana kepada penerima manfaat dan juga melakukan pendampingan program di lapangan. Hal ini sebenarnya menjadi suatu hal yang positif karena tidak berbelitnya struktur organisasi yang ada, sehingga implementor di lapangan bisa langsung melakukan koordinasi dan komunikasi dengan implementor di tingkat dinas.

\section{Komunikasi dan koordinasi}

Komunikasi dan koordinasi yang terjalin antar bagian pelaksana di dalam birokrasi akan sangat mempengaruhi implementasi sebuah program. Dari hasil wawancara yang dilakukan dengan Dinas Sosial dan PSM yang menjadi responden, mereka mengatakan bahwa proses komunikasi dan koordinasi mereka cukup baik. Bentuk koordinasi dan komunikasi antara PSM dengan Dinas Sosial bisa dalam bentuk formal misalnya dalam forum Workshop yang rutin diselenggarakan 2 kali dalam satu tahun oleh Dinas Sosial, undangan dari Ikatan Pekerja Sosial Masyarakat (IPSM) kepada Dinas Sosial jika masing - masing Kelompok Lansia di Kelurahan ada acara. Komunikasi dan koordinasi informal bisa langsung melalui telepon, SMS, WA antara pihak Dinas dengan PSM dilapangan atau sebaliknya. Menurut responden, justru komunikasi dan koordinasi ini yang efektif, karena sewaktu - waktu ada keperluan atau ada permasalahan bisa langsung melakukan komunikasi atau koordinasi.

Sementara itu, komunikasi dan koordinasi antara PSM dengan kelompok Lansia lebih sering dilakukan, antara lain di Forum pertemuan rutin bulanan kelompok lansia, di kegiatan Posyandu Lansia, dan kegiatan senam Lansia. Van Meter dan Van Horn (1975) menjelaskan bahwa dalam banyak program implementasi kebijakan, perlu hubungan yang baik antar instansi yang terkait, terutama soal dukungan komunikasi dan koordinasi. Koordinasi dan kerjasama antar organisasi sangat penting bagi keberhasilan suatu program karena menjadi salah satu penentu apakah program tersebut dapat direalisasikan sesuai tujuan serta sasarannya (Subarsono,2005)

Dari pemaparan diatas, dapat dianalisa bahwa untuk komunikasi dan koordinasi berjalan cukup baik, baik itu dari pihak Dinas Sosial ke PSM dan Kelompok Lansia, begitu juga sebaliknya. Hal itu bisa melalui jalur formal seperti workshop yang rutin diselenggarakan, rapat - rapat Dinas Sosial yang waktunya tentatif sesuai kebutuhan, rapat - rapat yang diselenggarakan IPSM atau Kelompok Lansia. Selain itu komunikasi non formal melalui telepon, SMS, ataupun WA justru dirasakan lebih efektif dalam melakukan komunikasi maupun koordinasi terkait program. Dengan demikian sebenarnya kondisi komunikasi dan koordinasi merupakan hal yang positif yang ditemukan dalam jalannya implementasi program ini di Kota Yogyakarta.

\section{Sumber daya manusia}

Sumber daya manusia merupakan hal yang penting dari kapasitas sebuah organisasi. Kemampuan pelaksana program dalam menerjemahkan isi pesan program kebijakan dan mengaplikasikannya di lapangan adalah hal yang sangat penting dalam proses implementasi program. Permasalahan sumber daya manusia yang terlibat dalam program ini dirasa kurang memadai. Yang dimaksud kurang memadai disini bukan dari segi komitmen, tanggungjawab, kemauan dan dedikasi tetapi dari hal kemampuan tekhnis PSM dalam melakukan pendampingan program UEP, karena mereka merasa tidak dibekali ilmu bagaimana bentuk pendampingan untuk program UEP, mereka hanya pernah diberikan pembinaan atau 
pembekalan untuk tenaga PSM secara umum, bukan pembekalan per program. Selain itu, dari sisi waktu PSM merasa bahwa waktu mereka sangatlah terbatas untuk melakukan pendampingan program UEP Lansia potensial ini, karena mereka juga mempunyai pekerjaan untuk program - program sosial lainnya, baik itu program dari Dinas Sosial, Dinas Kesehatan, BKKBN dan juga dari Kelurahan.

Hal tersebut memang benar adanya, karena kenyataan di lapangan bahwa mereka yang aktif dalam kegiatan kemasyarakatan misalnya menjadi kader PKK, Kader Posyandu dan lain - lain, orangnya itu - itu saja, tidak banyak orang yang mau meluangkan waktu untuk kegiatan atau pekerjaan sosial seperti yang mereka jalani. Bahkan PSM membandingkan dengan program lainnya, seperti program $\mathrm{PKH}$, dimana untuk program $\mathrm{PKH}$ ada pendampingnya khusus dan mendapatkan gaji, sehingga petugas pendamping PKH tersebut bisa fokus dan maksimal dalam melakukan pendampingan karena dari sisi pengetahuan program, tekhnis pendampingan jelas mereka sudah paham karena sudah diberikan pembekalan. Dari sisi waktu juga jelas lebih luang karena mereka khusus mendampingi program PKH. Harapan PSM bahwa kedepannya untuk program UEP ini jika memang benar - benar ingin maksimal hasilnya, maka perlu ada tenaga pendamping khusus.

Menurut Cheema dan Rondinelli seperti dikutip oleh Subarsono (2005), ada empat kelompok variabel yang mempengaruhi kinerja dan dampak suatu program yaitu: 1). Kondisi lingkungan; 2). Hubungan antar organisasi; 3). Sumber daya organisasi untuk implementasi program; dan 4). Karakteristik dan kemampuan agen pelaksana. Sementara menurut Goggin, dkk. (1990) menjelaskan bahwa jumlah SDM yang dimiliki oleh organisasi yang diberi mandat untuk mengimplementasikan suatu kebijakan akan memengaruhi kapasitas organisasi tersebut dalam menjalankan misinya untuk mewujudkan tujuan organisasi.

Data yang dipaparkan diatas dan kita hubungkan dengan teori dari Chemma dan Rondinelli terutama point ketiga mengenai Sumberdaya organisasi untuk implementasi program (dalam hal ini penulis melihat dari sisi sumberdaya manusianya) dan point keempat yaitu mengenai karakteristik dan kemampuan pelaksana atau implementor program, maka dapat dianalisa bahwa dari sisi sumberdaya manusia sebenarnya PSM mempunyai potensi yang baik, mereka memiliki komitmen, tanggungjawab, dedikasi yang tinggi terhadap pekerjaan sosial mereka, hanya saja pembekalan yang mereka dapatkan masih kurang, bahkan dibilang tidak ada pembekalan khusus mengenai kemampuan mendampingi program ekonomi produktif. Sehingga kemampuan tekhnis mereka dalam mendampingi program ekonomi produktif bisa dianggap kurang memadai.

Kemudian jika dikaitkan dengan teori dari Googin, mengenai jumlah sumberdaya manusia yang dimiliki akan berpengaruh kepada kapasitas organisasi dalam menjalankan programnya maka terbatasnya jumlah PSM dimasing-masing wilayah menyebabkan tugas PSM menjadi berat, ditambah lagi dengan menumpuknya pekerjaan-pekerjaan sosial lainnya yang harus mereka kerjakan sehingga alokasi waktu yang harus mereka berikan untuk mendampingi kelompok Lansia menjadi sangat terbatas, dan harapannya ke depan ada pendamping khusus untuk program UEP bagi Lansia Potensial. Kedua hal tersebut yaitu mengenai kemampuan tekhnis implementor yang kurang memadai untuk pendampingan program yang bersifat usaha ekonomi produktif dan juga faktor terbatasnya jumlah PSM dimasing - masing wilayah yang mengerjakan banyak tugas sosial lain selain pendampingan program UEP bagi Lansia potensial ini merupakan faktor negatif dalam implementasi program ini.

\section{Faktor Eksternal}

\section{Kondisi Lingkungan}

Peran masyarakat dalam penyelenggaraan kesejahteraan sosial lanjut usia secara simultan mengalami perkembangan yang sangat pesat pada akhir-akhir ini. Pesatnya pelayanan kesejahteraan sosial yang di selenggarakan oleh masyarakat di berbagai lapisan menunjukkan, 
bahwa penyediaan pelayanan sosial lanjut usia merupakan tanggung jawab pemerintah dan masyarakat.

Salah satu faktor eksternal yang berpengaruh terhadap implementasi sebuah program adalah kondisi lingkungan dimana program tersebut dijalankan. Dalam hal ini penulis membatasi apa yang dimaksud dengan kondisi lingkungan adalah kondisi sosial ekonomi, kondisi keamanan, kondisi politik, dukungan dari pemerintah setempat dan kondisi budaya yang ada dimasyarakat sekitar. Faktor-faktor positif dari variable-variabel tersebut tentunya akan menjadi faktor pendorong berhasilnya sebuah implementasi program, sebaliknya jika faktor-faktor negatif yang ada maka akan menjadi tantangan dan penghambat bagi implementasi sebuah program. Beberapa hal yang bisa dilihat dari kondisi lingkungan adalah:

\section{Keadaan sosial ekonomi dan politik kelompok masyarakat}

Kondisi sosial ekonomi masyarakat Kota Yogyakarta berdasarkan indikator - indikator kuantitatif Susenas yang dilakukan oleh BPS tidak akan dibahas dibagian ini, karena sudah dipaparkan secara rinci di bab sebelumnya yaitu di bab IV mengenai deskripsi wilayah penelitian. Pembahasan kondisi sosial ekonomi yang akan dibahas disini diambil dari pengakuan subyektif responden tersampel berdasarkan survey qualitatif yang penulis lakukan, karena memang penulis ingin melihat kondisi sosial ekonomi di wilayah sampel dimana program UEP bagi Lansia Potensial di implementasikan. Berdasarkan pengakuan responden, hasil yang didapatkan bahwa kondisi perekonomian memiliki tingkat kesenjangan yang cukup tinggi, karena di wilayah mereka tinggal banyak kalangan orang yang kaya yang memiliki usaha tetapi banyak juga masyarakat miskin yang matapencahariannya sebagai buruh. Kemudian untuk kondisi keamanan bisa dibilang cukup aman, tidak pernah terjadi tindak kriminal yang besar, hanya kasus pencurian kecil - kecil saja. Untuk tingkat partisipasi warga masih cukup baik untuk kegiatan kemasyarakatan misalnya untuk kegiatan gotong royong, pertemuan warga.

Kondisi sistem politik yang stabil dan demokratis cukup tercermin di Kota Yogyakarta, terutama didaerah penelitian. Mereka mengaku tidak pernah ada konflik antar warga yang disebabkan karena perbedaan pilihan atau pandangan politik yang ada. Walaupun ada perbedaan pandangan politik tetapi jika kembali ke kehidupan kemasyarakatan terutama untuk kegiatan - kegiatan sosial mereka tidak terpengaruh oleh perbedaan pandangan tersebut.

\section{Kondisi budaya keseharian masyarakat setempat}

Budaya keseharian disini adalah terkait dengan kebiasaan atau pandangan masyarakat terhadap implementasi program UEP bagi Lansia potensial. Dimana salah satu tujuan dari program ini adalah tetap mendorong Lansia melakukan usahanya atau bekerja untuk mendapatkan penghasilan supaya mereka bisa hidup mandiri. Terkait hal tersebut, penulis ingin mengetahui bagaimana sikap atau pandangan masyarakat disitu jika ada Lansia yang masih bekerja.

Dari hasil indepth dari beberapa informan maka bisa dikatakan bahwa masyarakat sekitar tidak mempermasalahkan Lansia bekerja untuk mendapatkan penghasilan. Dari pihak keluargapun banyak mendukung karena dengan masih beraktivitasnya orangtua mereka, maka justru orangtuanya relatif terjaga kesehatannya.

\section{Dukungan pemerintah setempat}

Dukungan dari pemerintah setempat ini baik dari level kelurahan maupun level Dinas. Dari beberapa informasi yang didapat hasilnya cukup beragam, ada yang berpendapat bahwa dukungan dari pemerintah kelurahan sangat kurang, bahkan banyak tidak tau mengenai program UEP ini. Sementara merunut teori yang sesuai dengan pembahasan diatas adalah teori menurut Mazmanian dan Sebastier (dalam Subarsono, 2005) yang menyebutkan terdapat 
tiga kelompok variabel yang berpengaruh terhadap implementasi suatu kebijakan yaitu: 1). Karakteristik dari masalah (tractability of the problem); 2). Karakteristik kebijakan/ undangundang (ability of statute to structure implementation); 3). Variabel lingkungan (nonstatutory variables affecting implementation). Di dalam variabel ketiga ini, yaitu variabel lingkungan kebijakan antara lain mencakup kondisi sosial ekonomi masyarakat dan dukungan publik terhadap sebuah kebijakan termasuk budaya masyarakat di lingkungan tersebut.

Dikaitkan antara data yang ada berdasarkan hasil wawancara dengan teori yang ada, maka dapat dilihat bahwa kondisi sosial, ekonomi, keamanan dan situasi politik yang kondusif di wilayah program merupakan faktor yang positif. Begitu juga faktor budaya dari masyarakat sekitar yang tetap mendukung jika ada Lansia yang masih bekerja, atau tidak ada norma yang melarang Lansia melakukan usaha atau bekerja juga bisa dikatakan sebagai faktor positif bagi pelaksanaan program. Tetapi jika dilihat dari kondisi dukungan birokrat setempat, terutama pihak kelurahan yang tidak tahu banyak mengenai program, dan hanya sebatas menandatangani proposal pengajuan dana tanpa ada perhatian lagi dalam pelaksanaan dan juga tidak adanya evaluasi dan pengawasan program dari pihak Dinas, maka hal tersebut bisa dikatakan sebagai faktor yang negatif dari pelaksanaan program ini.

Penerima manfaat program pandangan atau pendapat dari penerima manfaat sangatlah penting dalam melihat bagaimana implementasi sebuah program. Bagaimana kemudahan mengadopsi atau melaksanakan program dan sejauh mana program tersebut merubah kebiasaan yang dilakukan untuk memenuhi kebutuhannya. Kedua hal tersebut yang akan dipaparkan dibawah ini.

\section{Kemudahan adopsi atau pelaksanaan program oleh penerima manfaat}

Mudah atau tidaknya implementasi sebuah program bagi penerima manfaat sangat penting untuk dilihat, jika suatu program dalam pelaksanaannya justru menyulitkan si penerima manfaat untuk apa harus dilaksanakan program tersebut. Untuk program UEP bagi Lansia potensial ini pendapat dari para penerima manfaat cukup seragam, mereka berpendapat bahwa mudah saja bagi mereka karena pada dasarnya mereka sudah mempunyai usaha, sehingga uang tersebut digunakan untuk menambah modal usaha atau memberi perlengkapan lainnya. Mereka juga tidak dibebani untuk mengembalikan uang tersebut karena uang ini merupakan bansos yang bersifat hibah. Hanya saja memang tidak dipungkiri kondisi fisik mereka yang sudah melemah sehingga mereka melakukan kegiatan usaha sebatas kemampuan mereka sekarang.

\section{Perubahan kebiasaan}

Berubahnya kebiasaan dalam memenuhi kebutuhan sesuai dengan tujuan program merupakan hasil positif yang diinginkan sebuah program. Ketika hal ini ditanyakan kepada penerima manfaat program jika dilihat dari aspek ekonomis hampir semua informan mengatakan bahwa ada manfaatnya walaupun kecil yaitu untuk menambah modal atau untuk membeli peralatan baru. Tetapi dari beberapa informan baik dari PSM maupun penerima manfaat mereka mengakui hasil atau manfaat tidak langsung dari program ini adalah ke tingkat partisipasi Lansia di dalam kelompoknya. Dengan adanya bantuan UEP ini menjadi perangsang mereka untuk lebih aktif berpartisipasi dalam kegiatan - kegiatan kelompok Lansia, yang tentunya itu berdampak positif bagi kesehatan fisik maupun mental para Lansia.

Terkait dua variabel yang menyangkut kelompok sasaran atau penerima manfaat, teori yang bisa dijadikan rujukan untuk melihat pengaruh variabel adalah teori dari Quade yang menyebutkan bahwa faktor kedua dari empat variabel yang perlu diperhatikan dalam implementasi kebijakan publik adalah mengenai kelompok target, yaitu subjek yang diharapkan dapat mengadopsi pola interaksi baru melalui kebijakan dan subjek yang harus berubah untuk memenuhi kebutuhannya. Dari temuan data hasil wawancara, perihal yang 
pertama mengenai kemudahan dalam mengadopsi atau melaksanakan program, pihak penerima manfaat merasa tidak ada masalah karena dengan program ini mereka hanya tinggal melanjutkan usaha atau kegiatan mereka. Program yang berupa bantuan dana mereka manfaatkan sebagai tambahan modal dari usaha yang sudah mereka lakukan sebelumnya.

Hal kedua yang disebutkan teori tersebut yaitu mengenai perubahan yang terjadi pada penerima manfaat dari program ini, jika dilihat dari sisi ekonomi jelas tidak ada perubahan yang signifikan karena selain faktor bantuan yang kecil juga kondisi fisik penerima manfaat yang sudah tidak bisa lagi optimal dalam melakukan kegiatan usaha. Tetapi jika dilihat dari sudut pandang efek sosial, maka program ini memiliki efek perubahan pada kebiasaan penerima manfaat. Mereka menjadi lebih aktif berpartisipasi dalam kegiatan - kegiatan kelansiaan baik kegiatan sosial maupun kegiatan yang ada manfaatnya bagi kesehatan fisik mereka. Jelas hal ini membawa dampak positif bagi kesehatan mental dan fisik dari Lansia penerima manfaat program.

Kemudian dari sisi faktor - faktor yang mempengaruhi implementasi program, yang pertama dari faktor internal maka dapat disimpulkan bahwa konten kebijakan yang ditingkat nasional sudah cukup lengkap tidak didukung dengan kebijakan di daerah, karena di daerah belum ada peraturan tingkat daerah yang mengatur mengenai kesejahteraan lanjut usia. Selain itu pesan dari kebijakan yang sudah adapun tidak sampai ke tingkat implementor baik di tingkat dinas maupun implementor di lapangan, sehingga hal ini merupakan faktor negatif yang tentu saja menyebabkan tidak maksimalnya implementasi program di lapangan. Tetapi jika dilihat dari komunikasi dan koordinasi yang ada, implementasi program ini termasuk yang simple stucture, karena hanya Dinas Sosial yang terlibat langsung berhubungan dengan kelompok - kelompok Lansia penerima manfaat dan pendamping lapangan yaitu Pekerja Sosial Masyarakat (PSM). Hal ini sebenarnya menjadi suatu hal yang positif karena tidak berbelitnya struktur organisasi yang ada, sehingga implementor di lapangan bisa langsung melakukan koordinasi dan komunikasi dengan implementor di tingkat dinas. Sementara jika dilihat dari sisi sumber daya manusia, dengan tidak adanya pelatihan tekhnis yang khusus bermaterikan mengenai pendampingan usaha ekonomi produktif bagi pendamping lapangan menyebabkan pengetahuan dan keterampilan para PSM sangatlah kurang, selain itu jumlah PSM yang terbatas dan banyaknya tugas sosial lain yang mereka emban selain pendampingan program ini menyebabkan tidak maksimalnya mereka melakukan pendampingan bagi para penerima manfaat. Kedua hal diatas menjadi faktor negatif dalam implementasi program.

Selanjutnya, jika dilihat dari factor-faktor eksternal yang mempengaruhi implementasi program ini, beberapa hal yang bisa disimpulkan antara lain kondisi lingkungan. Dilihat dari kondisi sosial, ekonomi, keamanan dan situasi politik yang kondusif di wilayah program merupakan faktor yang positif. Faktor budaya juga merupakan faktor yang positif karena berdasarkan temuan yang ada, masyarakat sekitar yang tetap mendukung jika ada Lansia yang masih bekerja, atau tidak ada norma yang melarang Lansia melakukan usaha atau bekerja. Tetapi jika dilihat dari kondisi dukungan birokrat setempat, terutama pihak kelurahan yang tidak tahu banyak mengenai program, tidak adanya evaluasi dan pengawasan program dari pihak Dinas, hal tersebut bisa dikatakan sebagai faktor yang negatif dari pelaksanaan program ini. Kemudian dari sisi penerima manfaat, pertama perihal kemudahan dalam mengadopsi atau melaksanakan program, pihak penerima manfaat merasa tidak ada masalah dengan hal itu karena dengan program ini mereka hanya tinggal melanjutkan usaha atau kegiatan mereka. Hal ini merupakan faktor yang positif bagi implementasi program ini. Kemudian yang kedua, mengenai perubahan yang terjadi pada penerima manfaat dari program ini, jika dilihat dari sisi ekonomi tidak ada perubahan yang signifikan. Tetapi jika dilihat dari sudut pandang investasi sosial, maka program ini memiliki efek perubahan positif pada kebiasaan penerima manfaat. Tentu saja hal ini merupakan faktor positif pengaruhnya bagi implementasi program. 


\section{KESIMPULAN DAN SARAN}

Beberapa hal yang bisa disimpulkan bahwa implementasi program usaha ekonomi produktif bagi Lansia potensial di Kota Yogyakarta jika dilihat dari sisi kredibilitas pusat dirasa kurang, karena daerah melihat bahwa pusat hanya sekedar memaksakan kepada daerah untuk melaksanakan program tanpa ada dukungan pendanaan. Hal ini berimbas pada kecilnya dana yang digulirkan untuk program, karena murni mengandalkan APBD Kota. Efek domino yang ditimbulkan dengan kecilnya dana yang digulirkan maka berakibat pada sedikitnya jumlah sasaran penerima manfaat program sehingga efek dari program hanya menyentuh pada sebagian kecil dari total Lansia potensial yang ada di Kota Yogyakarta, hal ini sesuai dengan teori yang ada bahwa sumber daya finansial yang kurang dan juga kecilnya sasaran penerima manfaat dibandingkan populasi maka manfaat dari program kurang dirasakan secara maksimal oleh Lansia Potensial di Kota Yogyakarta. Dari sisi kendala yang ditemukan pada implementasi program ini cukup variatif, mulai dari sisi peraturan atau payung hukum di daerah yang dirasa belum lengkap, kapasitas dari PSM yang mendampingi dirasa kurang, baik dari sisi pengetahuan dan juga alokasi waktunya, kondisi dari Lansia yang secara fisik sudah menurun kemampuannya, dan ada juga beberapa kasus penyimpangan pemanfaatan bantuan yang dilakukan oleh penerima manfaat yang seharusnya digunakan untuk keperluan usaha tetapi justru digunakan untuk belanja kebutuhan konsumsi.

Penyusunan dan melaksanakan sebuah SOP mengenai monitoring dan evaluasi program yang jelas, sehingga bisa diketahui tingkat keberhasilan dari program tersebut. Tidak hanya sekedar program bagi - bagi dana bansos, tanpa diketahui bagaimana pelaksanaan dilapangan dan sejauh mana manfaat dari program tersebut. Selain itu mendorong pemangku kepentingan untuk meningkatkan peran serta komunitas yang di inisiasi pemerintah kelurahan dalam hal partisipasi Lansia dalam kegiatan - kegiatan kelanjutusiaan, sehingga akan lebih banyak ruang bagi lansia untuk berinteraksi sosial, mengekspresikan diri, melakukan usaha preventif dan kuratif kesehatannya yang diharapkan imbasnya adalah terbentuk Lansia yang sehat, mandiri dan bermartabat Terkait dengan permasalahan sumber daya manusia, mendorong adanya peningkatan kapasitas SDM bagi PSM, bisa dengan cara menugaskan seorang pendamping profesional untuk Program UEP bagi Lansia Potensial ini, atau dengan memberikan pelatihanpelatihan tekhnis kepada para PSM mengenai pendampingan usaha ekonomi produktif.

\section{DAFTAR PUSTAKA}

Abdul Wahab, Solichin .2008. Analisis Kebijaksanaan Dari Formulasi ke Implementasi Kebijakan Negara. Edisi kedua. Jakarta: PT. Bumi Aksara

Agustino, Leo. 2008. Dasar-dasar Kebijakan Publik. Alfabeta: Bandung

Badan Pusat Statistik, 2017. Statistik Penduduk Lanjut Usia Indonesia 2016, Jakarta

Badan Pusat Statistik, 2013. Proyeksi Penduduk Indonesia 2010 - 2035, Jakarta

Badan Pusat Statistik Kota Yogyakarta, 2016. Kota Yogyakarta Dalam Angka 2015, Yogyakarta

Badan Pusat Statistik Kabupaten Bantul, 2016. Kabupaten Bantul Dalam Angka 2015, Yogyakarta

Badan Pusat Statistik Kabupaten Sleman, 2016. Kabupaten Sleman Dalam Angka 2015, Yogyakarta

Badan Pusat Statistik Kabupaten Kulon Progo, 2016. Kabupaten Kulon Progo Dalam Angka 2015, Yogyakarta 
Badan Pusat Statistik Kabupaten Gunung Kidul, 2016. Kabupaten Gunung Kidul Dalam Angka 2015, Yogyakarta

Dunn, William N. Public Policy

Analysis : An Intoduction Second Edition (Pengantar Analisis Kebijakan Publik Edisi Kedua) Gadjah Mada University Press, Cetakan ke lima Maret 2003

Goggin, Malcolm L, dkk. 1990. Implementation, Theory and Practice: Toward a Third Generation, Scott, Foresmann and Company, USA

Moleong, L. J. 2012. Metodelogi Penelitian Kualitatif (Ed). Bandung: $\quad$ PT. Remaja Rosdakarya

Nugroho, Riant. 2003.KEBIJAKAN PUBLIK Formulasi, Implementasi, dan Evaluasi, Jakarta. Elex Media Komputindo

Purwanto, dkk, 2007, Metode penelitian Kuantitatif untuk Administrasi Publik dan Masalahmasalah Sosial, Yogyakarta, Gave Media

Quade, E.S. 1984. Analysis For Public Decisions, Elsevier $\quad$ Science Publishers, New York.

Saputro, Sulistyo, dkk. 2015. " Analisis Kebijakan Pemberdayaan dan Perlindungan Sosial Lanjut Usia" Deputi Bidang Koordinasi Penanggulangan Kemiskinan dan Perlindungan Sosial, Kementerian Koordinator Bidang Pembangunan Manusia dan Kebudayaan Republik Indonesia

Subarsono.2005. Analisis Kebijakan Publik : Konsep, Teori dan Aplikasi. Yogyakarta : Pustaka Pelajar

Sugiyono.2014. Metode Penelitian Kuantitatif, Kualitatif, dan Kombinasi (Mixed Methods). Bandung : Alfabeta

Winarno, Budi. 2002. Teori dan Proses Kebijakan Publik. Yogyakarta: Media Pressindo . 2007. Kebijakan Publik :Teori dan Proses. Yogyakarta Media Pressindo

Undang-Undang Republik Indonesia Nomor 13 Tahun 1998 Tentang Kesejahteraan Lanjut Usia.

Undang-Undang Republik Indonesia Nomor 13 Tahun 2003 Tentang Kesejahteraan.

Undang-Undang Republik Indonesia Nomor 11 Tahun 2009 Tentang Kesejahteraan Sosial.

Peraturan Pemerintah Republik Indonesia Nomor 43 Tahun 2004 Tentang Pelaksanaan Upaya Peningkatan Kesejahteraan Lanjut Usia. 